\title{
Assessing Institutional Factors Contributing To Loan Defaulting In Microfinance Institutions in Kenya
}

\author{
Gatimu, Eric Maina; Frederick Mukoma Kalui \\ A Research Project Submitted To Graduate School in Partial Fulfillment of the Requirements For The Award Of \\ Masters In Business Administration Of Egerton University
}

\begin{abstract}
The main goal of every microfinance institution (MFI) is to operate profitably in order to maintain its stability and improve growth and sustainability. However, existence of high levels of loan default problem in microfinance industry negatively affect the level of private investment and constrain the scope of microfinance institution credit to borrowers as MFIs have to compensate for loan default/delinquency losses. The success of individual MFIs in credit risk management is largely reflected in the proportion of delinquency's loans to gross lending. Factors such as credit policies, loan recovery procedures, and loan appraisal process are viewed as critical drivers of loan delinquency occurrence; each of these factors significantly affects loan delinquency performance in MFIs in Kenya. The study used primary data. The study target population compromise 59 MFIs registered by Association of Microfinance Institutions of Kenya (AMFIK). A descriptive survey design was used to carry out a census of 59 microfinance institution in Kenya, this is because of the small size population. The data was collected through a structured questionnaire and administered to MFIs loan officers for response. Multiple regression analysis was used to establish relationship between loan delinquency and credit policies, loan recovery procedures, and initial loan appraisal in MFIs in Kenya. A total of 48 questionnaires were administered of which 45 were adequately respondent to and considered for analysis, this formed $94 \%$ response rate. The findings indicated that all the three factors tested had a significant impact on the loan default rate, thus the micro-finance institutions have a cause to worry if they have to reduce the loan default rates by considering the three factors under the study.
\end{abstract}

\subsection{Background to the Study}

\section{Introduction}

The major goal of microfinance is the provision of micro loans to the low-income and the poor households. The chance that a microfinance institution (MFI) may not receive its money back from borrowers (plus interest) is the most common and often the most serious vulnerability in a microfinance institution. Since most microloans are unsecured, delinquency can quickly spread from a handful of loans to a significant portion of the portfolio. This contagious effect is exacerbated by the fact that microfinance portfolios often have a high concentration in certain business sectors. International organizations are coming to the realization that MFIs are veritable and effective channels to ensure programme implementation effectiveness, particularly in poverty alleviation projects and firsthand knowledge of the needs and interest of the poor (CGAP, 1999).

According to (Schreiner, 2003), the World Bank Sustainable Banking with the Poor project (SBP) in mid-1996 estimated that there were more than 1,000 microfinance institutions in over 100 countries, each having a minimum of 1,000 members and with 3 years of experience. In a survey of 2006 of such institutions, 73 per cent were NGOs, 13.6per cent credit unions, 7.8 per cent banks and the rest savings unions. An overwhelming majority of the world's poor live in the third world countries. Various approaches have been employed in alleviating poverty of which provision of credit that targets the poor is one. Many are now of the opinion that allowing the poor to have command over resources through credit can contribute towards poverty alleviation. (Bystrom, 2007) argues that the best way to do something about poverty is to let the people do their own thing. Nobody will have more motivation to change his situation than the sufferer himself/herself.

Micro-financial institution that offers savings and credit services is facing realities of market competition due to the liberalization of the economy, excess liquidity in big commercial banks, inadequate financial resources resulting to low liquidity in lending institutions among other factors (Dinos et al, 2010). The microfinance institutions have now become a household-name as millions of Kenyans rely on them, almost entirely for their basic needs of food, shelter and clothing and even school fees and medical expenses. They exist as viable and credible alternatives to formal banking institutions which to a large extent are beyond the reach of ordinary Kenyans. They provide the financial support and advantage which lies in the strong structure and shared values of trust mutual and development. They have mobilized funds over kshs. 150 billion making them one of the major contributors to national economy. The Micro financial Act 2008 required that loans policy and procedures manual specifying the criteria and procedures applicable in the evaluation, processing, 
approval, documentation and release of loan or credit facilities are put in writing by every licensed society. Loans must be disbursed according to the established credit policy and procedures as given by (Schreiner, 2003).

A written loan policy statement was beneficial as it communicated to employees in the loan department what procedures they must follow and what their responsibilities were. Therefore it helped the organization to move towards a loan portfolio, controlling its risk exposure and satisfying regulatory requirements (Joana, 2000). Any exceptions to the policy should be fully documented and reasons for it listed. While any written policy must be flexible due to continuing changes in economic conditions and regulations, violation of loan policy should be infrequent events. Loans department should consider all such changes and periodically review all loans until they reach maturity. Loan review is crucial as it helped management to identify problematic loans more quickly and acted as a continuing check on whether loans policy was adhered to by loan officers. The commercial banks reviewed loans more efficiently such that they were able to top up loans-faster using modern technology unlike institutions (Craig, 2006). According to Beatriz (2007), it was revealed that the study underscored the need to formulate a prudent credit policy for individual manufacturing firms as well as the need for a conducive macro and micro environment in order to synchronize benefits of using credit facilities to facilitate financial mobilization of firms which can be likened to institutions also. Therefore formulation of a prudent credit policy for institution is important to avoid loss of its market to its rivals and improve performance in terms of development.

According to Fofack, (2005)the types of loan offered by institutions are mainly short-term and longterm loans. The short-term loans are those repayable within a year and are usually meant for school fees and other emergency expenses. The amounts are generally small is guaranteed by government and did not help farmers to increase their overall earning capacity. Long-term or development loans arc for larger amounts and had a longer term effects. They helped farmers to increase their earning capacity through success of projects financed by these loans. Repayment period was usually for more than one year, No collaterals are given by members in form of property pledged except the secured guarantors and thus management should consider securing them in that manner. There was evidence that repayment of institutions loans was not being taken seriously by members due to low interest rate charged, lack of suitable guarantors and poor management systems for loan collection. As a result most of them were caught up in serious cash flow problem. The situation was complicated further by overdrafts whereby institutions negotiated with commercial banks at higher interest rates are loaned to members at lower interest rates (Pamoja,2010).

The borrower's credit worthiness is the ability of a customer to pay out the credit as and when due with a comfortable margin of error. This usually involves a detailed study of five aspects of loan application: character, capacity, cash, collaterals and conditions. Character refers to customer's responsibility, truthfulness, serious purpose and intention to repay loan. If the customer is insincerely promising to use borrowed funds as planned and in repaying as agreed, the loan should not be made to avoid a credit problem. The loan officer must be convinced that a customer has a well defined purpose for requesting a credit and has a serious intention to repay. Capacity to borrow money refers to the authority to request a loan and the legal standing to sign a binding loan agreement by a customer. Thus the borrower must not be a minor and supportive documents must be provided for example a copy of resolution of I borrowing company or pay-slip of an employee. According to Srinivasan, R. (2007) capacity refers to the income available to make repayment. Having a substantial income, holding the same job for several years and having few other debt payments suggest a strong financial capacity to repay.

Credit risk management should include strict delinquency monitoring, loan-loss provision and collection procedures. Credit risk is measured most accurately when loans are approved and processed on the basis of "five Cs"-character, capital or cash, capacity, 'collateral and conditions. Loans must be disbursed according to established credit policies and procedures. Loan analysis should therefore be guided by the formula: purpose, repayment schedule, amount applied for, collaterals, terms of loan agreement, interest rate chargeable, applicant's character and experience that a member or loanee has to fulfill the purpose of loan. Craig, (2006) describes non-performing loan as that loan that is in default or close to default. Many loans become non-performing after being in default for three months, but depend on the contract terms. A loan is nonperforming when payments of interest are past due by 90 days or more or at least 90 days of interest payments have been refinanced or delayed by agreement or payments are less than 90 days overdue but there are other good reasons to doubt that payments will not be made in full.

Credit is major form of external finance used by households, firms and governments in economy (Peeters, 2003). Credit finance encompasses any financing which requires unconditional payment or settlement in the future. In Kenya, credit continues to play an important role in the country's economy. The Central Bank of Kenya has estimated that the total domestic credit as at 30th June 2009 was reckoned Kshs. 408billion (CBK, 2007). When borrower approaches a financial institution for a loan facility the intention is to use it to finance a planned project and eventually repay the loan. Customers borrow funds for various reasons. The most common 
objectives for borrowing are for acquisition of assets like house, land or cars. As for business people, the need for funds would be to increase stock -in- trade, capital level or meet some current expenditure .In addition to the above primary needs the borrowers do sometimes approach financial institutions for bridging finance to take care of short-term needs.

\subsection{Statement of the Problem}

The microfinance movement is growing at a very rapid rate. In Kenya, the average year-on year increase in the portfolio of the Kenyan microfinance sector over the period 2004-2009 was 107\% (as compared with a mere 4\% increase in commercial bank lending in 2008-09). According to FSD (2010), in the year 2009 microfinance institutions in Kenya were serving $17.9 \%$ of the total number of individuals in the financial sector as compared to $7.5 \%$ in the year 2006. While East Africa is at an earlier stage of competition, the major urban centers in Kenya, especially Nairobi, are becoming saturated by competition among numerous MFIs.

Competition among MFIs has not only brought benefits such as better access and lower interest-rates, but has also introduced problems (Saloner,2007). These adverse effects fall back not only on the MFIs, which are struggling to maintain their performance level, but also on the clients. Borrowers are facing serious problems from paying back their loans. According to Peeters, (2003), $25 \%$ of borrowers in microfinance institutions take loans from six or more different financial institutions which eventually lead to repayment crisis in the microfinance industry. Repayment crisis subsequently lead to liquidity problems which negatively influence the operational performance of microfinance institutions.

Despite its importance due to the increasing competition in the microfinance industry in Kenya, there is no record available to this study on the factors contributing to loan defaulting in MFI's in Kenya. Several research studies have been conducted on the microfinance industry. For instance, Njeru, (2011) conducted a study on the nature of competition within micro finance industry in Kenya, examined how lending organizations predicted loans default rates among its clients and did a study on the linkages between micro finance institution and commercial banks economics in Kenya. However, none of these studies focused on the factors contributing to loan defaulting in micro-finances in Kenya, thus the essence of the study.

\subsection{Research Objectives}

The general objective of the study was to investigate the factors contributing to loan defaulting in micro-finances in Kenya.

The specific objectives of the study were:-

(i) To find out whether credit policies contribute to loan defaulting in microfinance institutions in Kenya.

(ii) To establish whether initial loan appraisal process contribute to loan defaulting in microfinance institutions in Kenya.

(iii) To determine whether loan recovery procedures contribute to loan defaulting in microfinance institutions in Kenya.

(iv) To determine the overall institutional factors that contribute to loan defaulting in microfinance institutions in Kenya

\subsection{Research hypotheses}

$\mathrm{Ho}_{1}$ : There is no statistically significant difference in loan defaulting due to credit policies

$\mathrm{Ho}_{2}$ : There is no statistically significant difference in loan defaulting due to initial loan appraisal process

$\mathrm{Ho}_{3}$ : There is no statistically significant difference in loan defaulting due to loan recovery procedures

$\mathrm{Ho}_{4}$ : There is no statistically significant factors that influence loan defaulting in microfinance institutions in Kenya

\subsection{Significance of the Study}

The study results will provide a useful reference document to loan policy developer. It will be used by micro-finances in developing appraisals systems and loan collecting procedures. This document will also be used by other financial institutions to ensure they maintain a performing portfolio. The managers and credit officers will find the document relevant in delinquency management. The study findings will help the prospective loan seekers to make an optimal decision whereby they are able to choose a source of finance with minimum cost and optimum benefits both in the short run and long run period. Thus their choice of either institution loan or commercial bank loan will be a knowledgeable decision unlike the scenario whereby many people are ignorant about the cost element of loan capital specifically. The study will provide background information to other researchers or scholars who would like to investigate more on factors contributing to loans defaulting. The finding will further provide secondary material for student in micro-finance and will encourage and motivate on diverse issues on loan defaulting and micro-finance. 


\subsection{Scope of the Study}

The study comprised of all microfinance's registered by Association of microfinance institute Kenya as at $31^{\text {st }}$ December 2012. There were 40 microfinance institutions in Kenya as at that date.

\subsection{Limitation of the Study}

The research was affected by the following limitations:-

The unwillingness of the respondents to supply the right response was a limiting factor. The respondents felt that there was no benefit in giving the right answers to the questions and for fear that other institutions will use the same to achieve their goals. The researcher obtained the consent of the various microfinance's to be visited. This was done by an official letter from the university and an introductory letter from the researcher.

\subsection{Definitions of key Terms}

Past due - This is loan installment that has not been paid at the period stipulated in the loan contract.

Arrears - Refers to a late payment, partial payment or a skipped payment.

Default - Default refers to a situation where a loanee fails to repay a loan. It occurs when a borrower cannot or will not repay the loan and the MFI no longer expects to receive payment.

Delinquency - In micro-finance this term refers to a situation where a loan is past "due". It is an occurrence in a loan portfolio where payments are in arrears. A loan account is termed as delinquent when payment is due and a loanee has failed to honor a payment obligation at the stipulated time.

Micro-finance - The provision of financial services to low - income clients including the self - employed.

Loss - A situation whereby the borrower is unable to pay loan because he is financially incapable and security value of property visa-visa the outstanding loan is low.

Non - Performing loan - A loan that is not paid or serviced as per agreement

Policy - Broad guidelines spelling out the expectation of the organization on long term basis.

Credit terms - These are the conditions that have to be met before the loan is approved.

Security - Saving clients want to be sure that their savings are safe and that the institution that collects them is stable.

\subsection{Introduction}

\section{Literature Review}

This chapter reviews the relevant literature in area under study. It includes that, theoretical framework, the factors contributing to loan defaulting and the conceptual framework. The chapter also covers the empirical studies related to this study.

\subsubsection{Historical Background of Microfinance Institutions}

Microcredit and microfinance are relatively new terms in the field of development, first coming to prominence in the 1970s, according to Robinson (2001). Prior to then, from the 1950s through to the 1970s, the provision of financial services by donors or governments was mainly in the form of subsidised rural credit programmes. These often resulted in high loan default, high loses and an inability to reach poor rural households (Schreiner, 2003).

Robinson states that the 1980s represented a turning point in the history of microfinance in that MFIs such as Grameen Bank began to show that they could provide small loans and savings services profitably on a large scale. They received no continuing subsidies, were commercially funded and fully sustainable, and could attain wide outreach to clients (Robinson, 2001). It was also at this time that the term "microcredit" came to prominence in development (Dinos \& Ashta 2010). The difference between microcredit and the subsidized rural credit programmes of the 1950s and 1960s was that microcredit insisted on repayment, on charging interest rates that covered the cost of credit delivery and by focusing on clients who were dependent on the informal sector for credit (Craig, 2006). It was now clear for the first time that microcredit could provide large-scale outreach profitably.

The 1990s "saw accelerated growth in the number of microfinance institutions created and an increased emphasis on reaching scale" (Robinson, 2001). refers to the 1990s as "the microfinance decade". Microfinance had now turned into an industry according to Robinson (2001). Along with the growth in microcredit institutions, attention changed from just the provision of credit to the poor microcredit, to the provision of other financial services such as savings and pensions microfinance when it became clear that the poor had a demand for these other services (Joanna, 2006). The importance of microfinance in the field of development was reinforced with the launch of the Microcredit Summit in 1997. The Summit aims to reach 175 million of the world's poorest families, especially the women of those families, with credit for the self-employed and other 
financial and business services, by the end of 2015 Beatriz, (2007). More recently, the UN, as previously stated, declared 2005 as the International Year of Microcredit.

\subsubsection{Micro Finance Institutions}

Micro-finance is the provision of the financial services to low income clients including the self employed (CGAP, 1999). The reserve bank of India has defined microfinance as provision of thrift, credit and other financial services and products of very small amount to the poor in rural, semi-urban and urban areas for enabling them to raise their income levels and improve the living standards. Financial services include savings and credit. Therefore the definition of Micro-finance will include both financial and social intermediation. According to (CGAP, 2010) micro-finance is a means of providing variety of financial services to the poor based on market driven and commercial approaches.

The history of micro-finance back dates to about three decades when Mohammed Yunus founded Micro-finance in 1976. The micro-finance started offering in Bangladesh to poor women. He established the Grameen Bank. Grameen is a Bengah name which means village. (Karimi, et al. 2003). Its evolution however dates back 30 years from the late 1960s with the efforts made toward reduction of poverty through the promotion o income earning activities among the poor. It is an up growth small enterprise development initiative. In providing services to its clients the micro-finances apply three approaches. The methodologies are individual lending, solidarity group lending and group of groups. The micro-finance in Kenya has greatly contributed to the uplifting of the status of the low income earners to a point that the banks are competing for the customers that they refused before. Kenya micro-finance is one of the oldest and most established in Africa. Its roots can be traced back to mid 1950s when the jot loan board scheme was established to provide credit to indigenous Kenyan with small trading businesses. In 1970s the main organization provides credit to micro and small enterprises (MSEs) (Latifee,2006)

The main organization providing credit was Christian organizations for example the NCCK (National Council of Churches of Kenya) and small church based NGOs (Non-Governmental Organizations). Not until 1980 when two major micro-finances emerged, K-Rep which started as a subsidiary of United States based NGO and the Kenya Women Finance Trust. K-rep Bank was founded in 1984 with goals to generate employment and increase incomes by expanding financial services to poor people. Its core business is to serve low income people especially those operating very small and micro enterprises as a means of facilitating their participation in the economic development of this country. The organization provides and introduced alternative credit delivery mechanism for the poor that consisted of small amounts without the requirement of tangible collaterals. The development of micro-finance industry in Kenya went up a notch or more than K-rep obtained banking license in 1999 and became the first micro-finance to be converted into a bank Samanath, (2009).

\subsection{Development of Micro Finance in Kenya}

The Kenyan Microfinance industry is one of the oldest and most established in Africa (Field \& Pande, 2008). Interest in informal sector in Kenya date back as early as 1970 s after the seminal International Labor Organization (ILO) report on employment was issued to Kenya in 1972. The report identified the informal sector as a potentially important contributor to employment and economic growth in Kenya and other developing countries. In the 1970's the main organization providing credit to the informal sector were church based organizations such as National Council of churches of Kenya (NCCK) and other smaller church based NGOs. These programmes were heavily subsidized and were ad hoc additions to other social outreach programmes offered to the poor. Outreach was extremely limited. In the 1980's other specialized organizations which included KREP, a subsidiary of a U. S. based NGO and Kenya Women Trust (KWFT) began operations. These programmes were heavily subsided and credit and training approach to assist microenterprises. In the 1990 's, interest and knowledge about the microfinance industry had grown substantially and the approach to the industry became more focused and sustainability oriented (Peeters, 2003).

Kenyan microfinance has shown resiliency despite local droughts and high inflation rates that afflicted the nation in 2008 and 2009. With the Kenyan government and the Central Bank of Kenya emphasizing financial access as a key to modernizing the economy, the sector has been strengthened by progressive policies and innovative approaches to delivering financial services. A large deposit base, along with the existence of well-developed MFIs, have allowed financial and operational expenses to remain relatively low and have led to some of the highest profitability measures in the region (Peeters, 2003).

In the 2000's, the microfinance sector witnessed emergence of large number of MFIs with some transforming to commercial banks and deposit taking institutions (DTM). The focus of these institutions gradually shifted from emphases on the very poor to the enterprise poor as demands on these institutions to be become financially sustainable increased. The Microfinance Act 2006 became operational in May 2008. The Act empowered the Central Bank of Kenya (CBK) to license and supervises deposit taking microfinance institutions. By December 2010, the CBK had licensed Faulu Kenya, Kenya Women Finance Trust (KWFT), 
SMEP, UWEZO and REMU as Deposit Taking Microfinance (DTMs) CBK, (2007) to conduct nationwide deposit taking microfinance business. As of May 2010, non-deposit-taking microfinance institutions did not fall under the jurisdiction of the Central Bank's microfinance regulations, and as such they fall under either the SACCO category supervised by the SACCO Societies Regulatory Authority (SASRA), or the informal microfinance category, which is unregulated except for the licensing required of all NGOs in Kenya CBK, (2007). The Central Bank is currently consulting with a variety of industry stakeholders to determine the best practices for incorporating non-deposit-taking MFIs into their regulatory framework. Four of Kenya's major commercial banks have roots in microfinance: two as building societies (Family Bank and Equity Bank) one as an NGO (KREP) and another as a cooperative society (Cooperative Bank). These commercial banks, along with a wide variety of registered microfinance institutions, savings and credit cooperatives, and NGOs, make up Kenya's microfinance industry. (Srinivasan,2007).

While Micro-finance approaches generally include some specific product design issues, a primary means of differentiating one approach from another is the choice of products and services provided and the manner in which the provision is made. Any approach must be based on the target markets and its demand for financial intermediation, as well as other products, contextual factors in the country, the objectives and institutional structure of the MFI. There are four well documented methods used in accessing credit to microentrepreneurs, namely individual lending, Grameen model solidarity and group lending village banking (Srinivasan,2007).

Individual lending is defined as the provision of credit to individuals who are not members of a group that is jointly responsible for loan repayment. It requires frequent and close contacts with the individual client. It is most successful for larger, urban based, production oriented businesses and for those who have some form of collateral or are willing consigner or with small scale farmers in rural areas, normally clients are those who require working capital and/or fixed assets (Frankel et al, 2000) Loan amounts and terms are bases on careful analysis by the credit offer. Detailed financial analysis and projections are often included with the loan application. The amount and terms are negotiated with the clients. Visit is often made to the clients place of business as specified in the loan contract. Savings may not only be provided depending on the institutional structure of the MFI. Training and technical assistance may be provided by the credit officers sometimes training in provided on a per-fee-basis or is mandatory (Frankel et al, 2000).

\subsection{Theoretical Frame Work}

The theories to discussed here below are, liquidity preference theory, Austrian theory of business cycle and the Grameen Solidarity Group theory

\subsubsection{Liquidity Preference theory}

The theory explains the traditional upward sloping yield curve as puts forward by Keynes John (Carter et al, (2004).The logic is that investors prefer short term securities which give them greater liquidity because due both interest risk and default risk the longer a security must be held till maturity. Holders of long-term securities bear the risk that interest rates will rise during the period making their fixed rate investments less valuable. Similarly unfavorable changes in the financial conditions of the company are also a function of time and today are more certain than tomorrow, next month is more certain than next year and thus the possibility of default increases over a longer period. Investors are therefore willing to accept the lowest rate of return only on the shortest term and most liquid securities.

They will require higher interest rate to compensate for the higher risks that go with longer terms. This theory underlies the significance role played by time value of money. It demonstrates that a shilling today is worth more than a future shilling because a shilling at hand is a sure shilling-it is has no uncertainties surrounding it. Such shilling can also be invested to fetch more returns on investments. This theory however fails clearly to demonstrate the wisdom behind investing a sure shilling at hand today in future investments whose certainty the same theory fails to clearly bring out. Hence, it's imperative that a study be undertaken to determine the factors influencing the non-performance of loans portfolio as part of future investments with uncertainty (Carter et al, (2004).

\subsubsection{Austrian Theory of the Business Cycle}

The Austrian theory of the business cycle emerges straight forwardly from a simple comparison of a savings induced boom (Boldizzoni, 2008) .An increase in savings by households and credit expansion orchestrated by the central bank sets into motion market processes whose initial allocation effects on the economy's capital structure are similar but whose ultimate consequences are sharply different. The general argument of the theory though not the full argument can be stated in terms of the conventional macro-economic aggregates of savings and investments. The levels of investment are determined by the supply of and demand 
for loanable funds. Supply reflects the willingness of households to save at various rates of interest; demand reflects the willingness of business to borrow in order to finance investment projects.

Each represents a state of equilibrium in the loan market. An increase in the supply of loanable funds has obvious initial effects on the rate of interest and on the level of investment borrowing. But the ultimate consequences differ importantly depending upon whether the increase supply of loanable funds derives from increased saving by households or from increase credit creation by the central bank. Even in this simple loanable funds framework many aspects of the Austrian theory of the business cycle are evident. The natural rate of interest is the rate that equates saving and investment. The bank rate diverges from the natural rate as a result of credit expansion. When new money is injected into credit markets, the injection effects which the Austrian theorist emphasizes over price level effects take the form of too much investment. (Boldizzoni,2008).

Other significant aspects of the Austrian theory of the business cycle can be identified only after the simple concept of investment is replaced by the Austrian vision of a multi-stage time-consuming production process. The rate of interest governs not only the level of investment but also the allocation of resources within the investment sector. The economy's inter temporal structure of production consist of investment subaggregates which are defined in terms of their temporal relationship to the consumer goods they help to produce. Some stages of production such as research and development and resources extraction are temporally distant from the output of consumer goods. As implied by standard calculations of discounted factor values interest rate sensitivity increases with the temporal distance of the investment sub aggregate or stage of production from final consumption (Boldizzoni,2008).

An increase in the rate of saving implies a change in the preferred consumption pattern such that planned consumption is shifted from the near future to the remote future. A savings induced decrease in the rate of interest favors investment over current consumption. Significance in Austrian theorizing it favors investment in more durable over less durable capital and in capital suited for temporally more remote rather than less remote stages of production. These are the kinds of changes within the capital structure that are necessary to shift output from the near future to the more remote future in conformity with changing inter temporal consumption preferences. (Boldizzoni, 2008).

This theory puts more emphasis on long-term investments running into the remote future with emphasis that such remoteness is likely to fetch higher interest rate for the firm. While this sounds prudent in theory, in practice such financial management principle may end up starving the organization of the short-term interest to run its day to day operations in anticipation of future booming interests. In any event even the time value of money is also not catered for in this theory. By extension the theory also does not provide a caveat on exactly what happens in the event that the interests payable and even the capital accrued from long -term loans is not forthcoming. This is a research gap that must be filled so as to determine the factors influencing nonperformance of loans especially in public financial corporations.

\subsubsection{The Grameen Solidarity Group Theory}

This model is based on group peer pressure whereby loans are made to individuals in groups of four to seven (Armendariz et al, 2005). Group members collectively guarantee loan repayment, and access to subsequent loans is dependent on successful repayment by all group members. Payments are usually made weekly According to Armendariz et al, (2005). solidarity groups have proved effective in deterring defaults as evidenced by loan repayment rates attained by organizations such as the Grameen Bank, who use this type of microfinance model. They also highlight the fact that this model has contributed to broader social benefits because of the mutual trust arrangement at the heart of the group guarantee system. The group itself often becomes the building block to a broader social network.

According to the study by (Waweru et al, 2009) the lending procedure used by micro financial institutions have been bound by banks as an entry point through developing a very simple and unsecured procedures that include the submission of loanees identification card, letter of introduction from employer. Kenya Revenue Authority P.I.N. number, a loan form duly filled and current pay slips for at last three months. Terms and conditions of micro financial institutions are many and rigid unlike banks because a member is required to provide guarantors, boost his share savings and cannot be advanced a loan which will attract a deduction of more than two thirds of his or her basic pay despite the amount of shares held, which allows him to get a loan of about three times his/her shares. This eventually leaves the amount of loan disposable to the poor less than that advanced by banks thus becomes preferred by many rural members (Mugwanga et al, (1999).

\subsection{Factors Leading to Loan Defaulting in Microfinance}

Every loan issued comes with definite terms and Conditions and for as long as it is outstanding. Scheduled and periodical payments are tracked using a variety of methods and procedures ranging from cheque issue, clearance, loan money collection and deposit, reflection on periodical reports that are issued on weekly, 
monthly, quarterly or other basis depending on the micro-finance organization. The loan portfolio is the outstanding loan balance and the income earner and is the primary investment of the program. (Buvinic, 1997).

\subsubsection{Loan Appraisal}

A loan appraisal is a request/application for loan/funds on credit evaluated on its merits by a microfinance institution. Among others aspects, the purpose of loan, genuineness of its need, its quantum, borrower's repayment capacity, security etc are assessed on some parameters before loan is actually granted. Loan appraisal process plays a big role in assuring the lender of minimal circumstances on losing his/her money hence if the officers designated to loan appraisal are competent then high chances of leading money to non deserving customers would be high. . (Boldizzoni, 2008).

\subsubsection{Credit Policy}

Credit policy can be defined as a Clear, written guidelines that set the terms and conditions for customer qualification criteria, procedure for making collections, and steps to be taken in case of customer delinquency. Lack of clear Credit policies can lead to default of repayment of microfinance loans, if microfinance does not have stringent credit policies then they stand to lose their money hence creating liquidity issues.

\subsubsection{Collection Procedures}

A collection procedure is a detailed statement of steps to be taken regarding when and how the past-due amounts of a debt are to be collected. Each company has its own collection procedure, with information such as due dates, grace periods, penalties, date of repossession, date of turnover of delinquent account to collection agency, among others. The collection procedure for any loan arrangement should be spelled out as part of the loan terms. It is important for borrowers to be aware of he details of the collection procedure so as to avoid penalties, and in the case of collateral or secured loans, repossession of the collateral. While collection procedures may vary for each company they should all be complaint with existing laws. Third party collection agencies must also adhere to set Acts, not just in the collection procedure details but also the manner in which the collection takes place (Latifee, 2006).

The Acts specifies not only collection procedures to be followed by government financial institutions, but also specifies that a person or organization indebted to the United States, against whom a judgment lien has been filed, is ineligible to receive a government grant. What this means is that it is of utmost importance to comply with the debt collection act, especially since non-compliance carries with penalties that can range from steep fines to imprisonment. If microfinance institutions do not come up with well administered collection procedures then this could be a recipe for one defaulting to repay the loan (Boldizzoni, 2008).

\subsection{Empirical studies}

According to Fidrmuc et al,(2007) who sought to find out whether a lender extends credit to customers it recognizes the possibility that customers will be unable to pay or unwilling to pay as his objective. This study adopted a survey research design targeting all types of lenders. He found out that lenders must establish policies for determining who will receive credit for how long and how much. He also found out that lender should built their credit policy around five of credit that character capacity capital collateral and conditions for them to be successful. He concluded that borrowers may sometimes fail to pay back loans due to lack of financial ability and other related factors other than not being willing to pay for credit given.

Njeru, B. W. (2011). who sought to find out about public debt his objective being the structure and servicing of Kenya 's public debt. She utilized a descriptive survey targeting Kenya as a country as his research methodology in studying the structure and servicing of Kenya's public debt. Her study findings were: the Government was not happy with the level of stock of domestic debt and the government was not supporting the private sector has it should. She concludes that for government needs to put in place measures to reduce its public debt. As part of the measures of addressing the problem, she concludes that that the Government should support the private sector to make it more productive and in the process raise Gross domestic product.

On the other hand Rose, (2002) in her study on credit analysis had her objective of finding out whether credit analysis is important in ensuring that institutions maintain good loaning policy. She adapted a case study design targeting one organization and analyzed the findings quantitatively. She found out that credit analysis is important in ensuring that institutions maintain good loaning policy. The credit department must answer three questions regarding each loan application that is: the borrower credit worthy?; can the loan agreement be properly structured and documented for adequate protection of stakeholders and ensure that customer's probability of loan repayment is high without excessive strain? And can the institution perfect its claim against the assets or earnings of the customer so that, in the event of default the funds can be recovered rapidly at low 
cost and with low risk? She concluded that organizations had a duty to analysis their credit mechanisms if they intend to achieve a good loaning policy.

Mwaura`s (2003), sought to find out the responsiveness of manufacturing firms on credit policies, his objective was find out how whether individual manufacturing firms credit policy was prudent. He used descriptive survey design targeting the entire manufacturing firms in Kenya. He found out that manufacturing firms did not formulate prudent credit policies and that their performance was affected by a lack of these policies. He concluded that there was need to formulate a prudent credit policy for individual manufacturing firms. The formulation of a prudent credit policy for institution of this nature is important to avoid loss of its market to its rivals and helps them to improve performance in terms of development.

\subsection{Conceptual Framework}

The diagrammatic representation of conceptual framework shows how the variables were related. Loan appraisal credit policy, loan recovery and loan appraisal are independent variables, loan default of loan repayment is dependent variable which depends on the occurrences of the said independent variables.

\section{Figure 2.6 Conceptual framework}

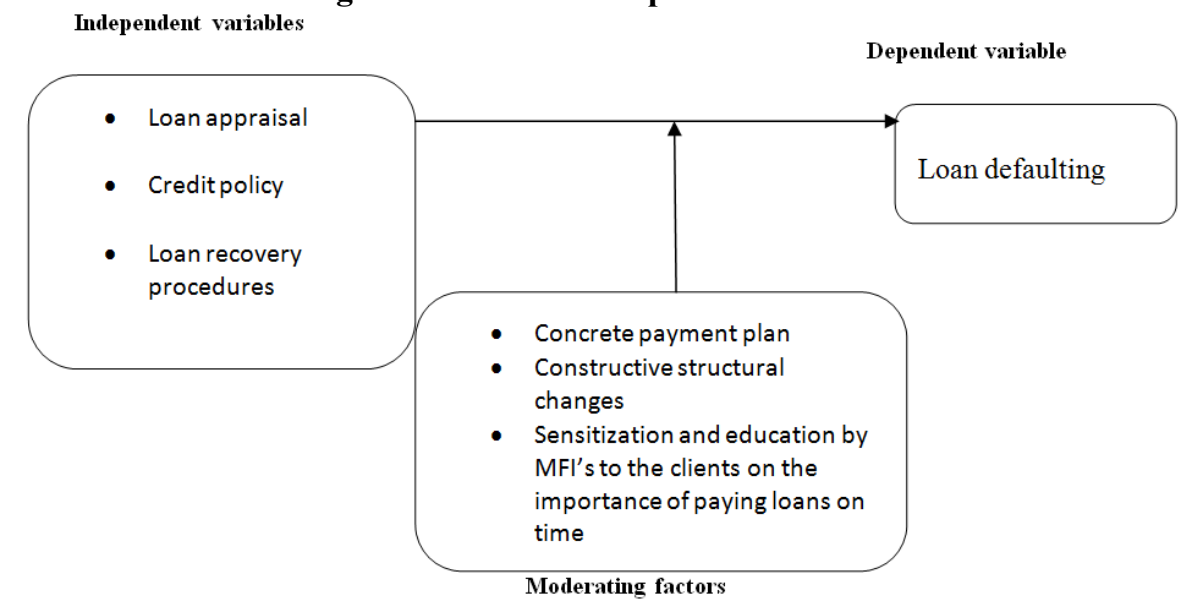

Source: Author (2013)

The dependent variable of this study was loan default which was influenced by various independent variables. The independent variables considered in the study were economic cycles / factor, loan appraisal, credit policies and loan recovery procedures.

\subsubsection{Loan Policies}

Loan policies to a great extent influence loan default. Poor loan policies while increase loan default rates while well formulated policies reduce loan default rates.

\subsubsection{Initial Loan Appraisals}

Initial loan appraisals determine the level of loan default. This involves the use of false information or means to acquire loans from lending institutions. These might also include giving or accepting collaterals whose values have been overstated and impaired. Some borrowers who might have falsified their business past performance of records in order to acquire loans would not be able to repay comfortably later. The initial loan appraisal therefore, includes the core five ingredients of loan appraisal. This comprise of tests on accuracy, honesty, collaterals, capacity and cash flow to determine loanee's credit worthiness and there likelihood chances of loans default

\subsubsection{Loan Recovery Procedures}

The loan recovery procedures employed by various microfinance's will contribute to loans default to a greatest extent. Poor loan recovery procedures for example will create a huge portfolio of debt uncollected thus led to loans default and vice versa.

\subsubsection{Credit Policies}

At the same time the nature of credit policies including loaning terms and conditions as well as loaning procedures had the long term effect on loan default. The basic requirements a member will be required to meet to qualify for a loan in the institution determined whether or not that member would honour the loan repayment 
in future. Liberal, stringent and lenient credit policies had long-term consequences on the loan default. For instance, it is highly likely that lenient and liberal policies would almost automatically create a huge portfolio of loan default.

\subsection{Introduction}

\section{Research Methodology}

This chapter represents the research design, sampling design, sampling procedures, data collection, data analysis and reporting, limitations and expected outcomes.

\subsection{Research Design}

This study adopted a descriptive survey design of the factors contributing to loan defaulting. The main reason for the use of a descriptive survey design was to provide as much information on the entire population under study in relation to the factors contributing to loan defaulting in MFI's. This provided some data and perceptions of the population and they supported inferences of cause and effect on the topic under study. Survey designs are of particular value to researchers seeking help on investigating and analysis interrelationships of a number of factors involved, and in which it is difficult to understand the individual factors without considering their relationships with each other (Mugenda \& Mugenda, 1999).

\subsection{Target Population.}

The population of interest in this study consisted of all the 59 Mfi's registered by Association of microfinance institution-Kenya as at 31st December 2012 (both deposit and non deposit taking institutions). This included the 9 deposit taking Mfi's registered by the central bank of Kenya. As per the MFI bill 2002, the Central Bank of Kenya was mandated to register all the MFIs in Kenya, however as at the time of study, they had only registered deposit taking MFI's which numbered 9 and they were yet to register non-deposit taking MFI's, this leaves AMFI as the only formal body that registers MFIs in Kenya.

The researcher undertook a census of the 59 MFI's registered with the AMFI; one credit manager from the 59 MFIs was targeted for response. The census was chosen because of the small number of the population and secondly it reduced the margin of error that comes with sampling.

\subsection{Data Collection Methods and Instruments}

Methods of data collection that was used involved primary data. Primary data was derived from questionnaires distributed to senior managers in credit department of the targeted MFIs. The questionnaires had both open and closed-ended questions and covered factors contributing to loan defaulting in MFIs. The researcher personally administered the questionnaires. Questionnaire allowed for confidentiality of the respondents to be kept. The questionnaires contained information on credit policies, loan collection procedures loan appraisal system in relation to their contribution to defaulting.

\subsection{Data Analysis and Presentation}

Data was analyzed on the basis of descriptive statistics. Descriptive statistics describe data on variables with single numbers while analysis of variance (ANOVA) tests for any significance difference between mean values of variables. Arithmetic mean, median, maximum, minimum and the standard deviation are some of the main descriptive statistics applied in data analysis.

Pearson correlation was then performed to establish the significance differences between the independent variables and the dependent variable. $t$ - test was used to test for the significance of each predictor variables in the model. The null hypothesis (i.e. the model lacking explanatory power) was rejected when the significance value $\mathrm{t}$ - statistic is less than 0.05 (significance level).

A multiple regression model was used to test the hypotheses of the combined effect of the four independent variables (loan appraisal, loan recovery procedures, credit policies and economic factors) on the dependent variable (loan defaultance). The study was guided by the following regression model:

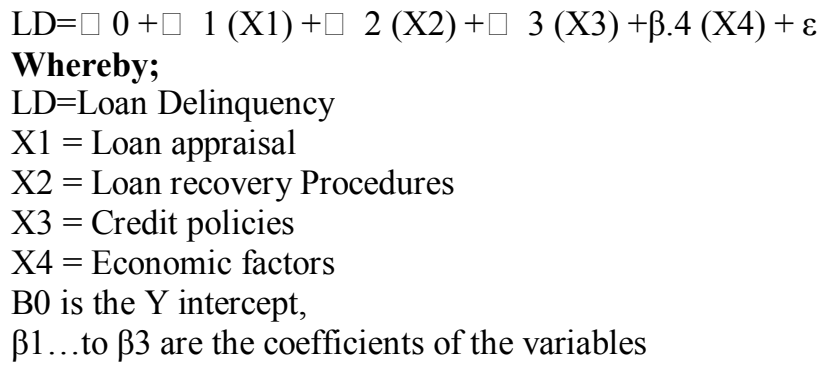


$\varepsilon=$ error term

\subsubsection{Reliability Analysis}

Reliability analysis was done to assess the reliability, internal consistency and validity of the survey instruments used. Reliability analysis was explained by Cronbach's reliability coefficient. The study made use of Likert scale hence suitability for reliability analysis. Likert scale enabled easier analysis as it removed doubt on the type of response given. Cronbach's alpha coefficient was pegged on Mugenda, and Mugenda rule of thumb (0.6). Cronbach's alpha is a measure of reliability.

\subsection{Introduction}

\section{Results And Discussion}

This study set out to investigate the factors contributing to loan defaulting in micro-finances in Kenya. . The data was collected using questionnaires targeting credit managers of the registered micro-finance institutions in Nairobi County. Out off 48 questionnaires issued 45 were returned back duly filled representing $94 \%$ response rate.

\subsection{Background Information of the Study Respondents}

\subsubsection{Respondents gender}

The researcher sought to establish the gender of the respondents from the micro-finance institutions. Majority of the respondents were female forming $56.3 \%$ while the male respondents were $43.8 \%$ as depicted in the table below

Table 4.1 Respondents Gender

\begin{tabular}{|l|c|c|}
\hline & Frequency & Percent \\
\hline Male & 20 & 43.8 \\
\hline Female & 25 & 56.3 \\
\hline Total & $\mathbf{4 5}$ & $\mathbf{1 0 0 . 0}$ \\
\hline
\end{tabular}

\subsubsection{Respondents Age bracket}

The researcher further sought to establish the issue of age bracket; the findings indicated half of the respondents $50 \%$ were below 30 years old, $37.5 \%$ were between $30-40$ years while $12.5 \%$ were between $40-50$ years old

Table 4.2 Respondents Age bracket

\begin{tabular}{|l|c|c|}
\hline & Frequency & Percent \\
\hline 18-30 years & 23 & 50.0 \\
30-40 years & 17 & 37.5 \\
40-50 years & 5 & 12.5 \\
Total & $\mathbf{4 5}$ & $\mathbf{1 0 0 . 0}$ \\
\hline
\end{tabular}

\subsubsection{Respondents level of education}

Majority of the respondents had attained the degree level of education forming $62.5 \%$, while $18.8 \%$ had attained diploma and masters levels respectively.

Table 4.3 Level of education

\begin{tabular}{|l|c|c|}
\hline & Frequency & Percent \\
\hline Diploma & 9 & 18.8 \\
Degree & 28 & 62.5 \\
Masters & 8 & 18.8 \\
Total & $\mathbf{4 5}$ & $\mathbf{1 0 0 . 0}$ \\
\hline
\end{tabular}

\subsubsection{Work experience with the organization}

When asked to indicate their work experience in their respective organizations, majority of the respondents $31 \%$ had worked for between $2-5$ years, $25 \%$ had worked for between $1-2$ years, $18.8 \%$ had worked for between 5-10 years and less than 1 year respectively while $6.3 \%$ had worked for over 10 years. 


\section{Table 4.4 Work experience}

\begin{tabular}{|l|r|r|}
\hline & Frequency & Percent \\
\hline Less than 1 year & 9 & 18.8 \\
1-2 years & 11 & 25.0 \\
2-5 years & 14 & 31.3 \\
5-10 years & 8 & 18.8 \\
Over 10 years & 3 & 6.3 \\
Total & $\mathbf{4 5}$ & $\mathbf{1 0 0 . 0}$ \\
\hline
\end{tabular}

\subsection{Descriptive Statistics}

The analysis started with computation of the descriptive statistics, under the credit policy, the minimum number of respondents were 12 while the maximum were 36 , the average was skewed to the left at -2.333334 and the deviation of the credit policy from the mean was 2.30940 , for loan appraisal process, the minimum respondents and maximum were 11 and 37 respectively, the average respondents was -3.66667 and the deviation from the mean was 3.05505, for loan recovery procedures the minimum and maximum number of respondents were 12 and 36 respectively, the average respondents was -3.33333 while the deviation from the mean was 2.51661 while for loan defaulting the minimum, maximum ,mean and standard deviations were 13 , $38,-2.25331$ and 2.16513 respectively.

Table 4.5 Descriptive Statistics $\mathrm{N}=45$

\begin{tabular}{|l|r|r|r|r|}
\hline & Minimum & Maximum & \multicolumn{1}{c|}{ Mean } & Std. Deviation \\
\hline Credit Policy & 12.00 & 36.00 & -2.33333 & 2.30940 \\
Loan Appraisal Process & 11.00 & 37.00 & -3.66667 & 3.05505 \\
Loan Recovery Procedures & 12.00 & 36.00 & -3.33333 & 2.51661 \\
Loan Defaulting & 13.00 & 38.00 & -2.25331 & 2.16513 \\
\hline
\end{tabular}

\subsubsection{Credit policy}

The researcher sought to establish how the different factors under the credit policy impact on the loan defaulting, $19 \%$ of the respondents indicated that poor loan facilities have no contribution on loan defaulting and least contribution respectively, $6 \%$ indicated that it has great contribution, $25 \%$ said it has greater contribution while the majority $31 \%$ indicated that it has the greatest contribution. When asked about strict repayment policies, majority 33\% indicated that it has leas contribution, $20 \%$ said it has great contribution, $13 \%$ said it has greater contribution while $27 \%$ said it has greatest contribution. For well formulated policies, $31 \%$ said it has least contribution and $25 \%$ said it has no contribution and greatest contribution respectively. For flexible loan policies $38 \%$ indicated that it has least contribution and greatest contribution. Majority of the respondents $50 \%$ said poor record keeping policies have greatest contribution on loan defaulting while $44 \%$ said the overall credit policies affect loan defaulting. These results actually concurs with (Mwaura,2003) findings that manufacturing firms did not formulate prudent credit policies and that their performance was affected by a lack of these policies hence the same, the microfinances need to come up with credit policies which will deter loan default. This confirms the same for (Fidrmuc et al,2007) whose findings were more or less on introduction of credit policies which will deter loan defaulters.

Table 4.6 Credit policy

\begin{tabular}{|l|l|l|l|l|l|}
\hline Variables & No contribution & $\begin{array}{l}\text { Least } \\
\text { contribution }\end{array}$ & $\begin{array}{l}\text { Great } \\
\text { contributio } \\
\text { n }\end{array}$ & $\begin{array}{l}\text { Greater } \\
\text { contributio } \\
\text { n }\end{array}$ & $\begin{array}{l}\text { Greatest } \\
\text { contributio } \\
\text { n }\end{array}$ \\
\hline Poor loan policies & $19 \%$ & $19 \%$ & $6 \%$ & $25 \%$ & $31 \%$ \\
\hline Strict repayment policies & $7 \%$ & $33 \%$ & $20 \%$ & $13 \%$ & $27 \%$ \\
\hline Well formulated policies & $25 \%$ & $31 \%$ & $19 \%$ & $0 \%$ & $25 \%$ \\
\hline Flexible loan policies & $13 \%$ & $38 \%$ & $6 \%$ & $6 \%$ & $38 \%$ \\
\hline Poor record keeping policies & $19 \%$ & $19 \%$ & $13 \%$ & $0 \%$ & $50 \%$ \\
\hline $\begin{array}{l}\text { To what extent does credit policies affect } \\
\text { loan defaulting }\end{array}$ & $13 \%$ & $6 \%$ & $19 \%$ & $19 \%$ \\
\hline
\end{tabular}




\subsubsection{Loan appraisal process}

When asked how the loan process affects the default rate, a half of the respondents said it bears the greatest contribution, $13 \%$ said it has no contribution and it has least contribution respectively while $19 \%$ said to the greater contribution. 50\% said use of false information to acquired loan have the greatest contribution, $31 \%$ said to greater contribution, $13 \%$ said to least contribution while $6 \%$ said to great contribution. When asked about how accepting collaterals whose values are overstated or impaired affect loan defaulting, $38 \%$ said to the greatest contribution. $44 \%$ said falsified past business performance records affects loan default, $25 \%$ said to the greatest contribution, $19 \%$ said to the least contribution while $13 \%$ said to great contribution. For poor tests of accuracy and honesty of applicants, $44 \%$ said it contributes to the greatest extent, $38 \%$ said it has greater contribution, $13 \%$ said it has great contribution while $6 \%$ indicated that it has no contribution on loan default rate.

Table 4.7 Loan appraisal process

\begin{tabular}{|l|l|l|l|l|l|}
\hline Variables & $\begin{array}{l}\text { No } \\
\text { contributio } \\
\text { n }\end{array}$ & $\begin{array}{l}\text { Least } \\
\text { contributi } \\
\text { on }\end{array}$ & $\begin{array}{l}\text { Great } \\
\text { contributi } \\
\text { on }\end{array}$ & $\begin{array}{l}\text { Greater } \\
\text { contributi } \\
\text { on }\end{array}$ & $\begin{array}{l}\text { Greatest } \\
\text { contributi } \\
\text { on }\end{array}$ \\
\hline $\begin{array}{l}\text { To what extent does loan appraisal affect loan } \\
\text { defaulting }\end{array}$ & $13 \%$ & $13 \%$ & $6 \%$ & $19 \%$ & $50 \%$ \\
\hline Use of false information to acquire loan & $0 \%$ & $13 \%$ & $6 \%$ & $31 \%$ & $50 \%$ \\
\hline $\begin{array}{l}\text { Accepting collaterals whose values are } \\
\text { overstated or impaired }\end{array}$ & $13 \%$ & $13 \%$ & $31 \%$ & $6 \%$ & $38 \%$ \\
\hline Falsified past business performance records & $0 \%$ & $19 \%$ & $13 \%$ & $44 \%$ & $25 \%$ \\
\hline $\begin{array}{l}\text { Poor tests of accuracy and honesty of } \\
\text { applicants }\end{array}$ & $6 \%$ & $0 \%$ & $13 \%$ & $38 \%$ & $44 \%$ \\
\hline
\end{tabular}

\subsubsection{Loan recovery procedures}

The researcher went further to inquire how the loan recovery procedures affect the loan default rate, $31 \%$ said listening to defaulters excuses to extend period said to greatest contribution, $25 \%$ said to greater contribution, $19 \%$ said to great contribution while $13 \%$ said to no contribution and least contribution respectively. When asked about uncommitted debt collectors $38 \%$ said to greater contribution, $31 \%$ said to greatest contribution, $19 \%$ said to least contribution while $13 \%$ said it had no contribution. $44 \%$ said long repossessing period contributes to greatest contribution while $19 \%$ said it contributes the least, great contribution and greater contribution respectively. $50 \%$ of the respondents said corrupt staff/officers have the greatest contribution, $25 \%$ said it have no contribution while $13 \%$ said to great contribution and greater contribution respectively

Table 4.8 Loan recovery procedures

\begin{tabular}{|l|l|l|l|l|l|}
\hline Variables & No contribution & $\begin{array}{l}\text { Least } \\
\text { contribution }\end{array}$ & $\begin{array}{l}\text { Great } \\
\text { contribution }\end{array}$ & $\begin{array}{l}\text { Greater } \\
\text { contribution }\end{array}$ & $\begin{array}{l}\text { Greatest } \\
\text { contribution }\end{array}$ \\
\hline $\begin{array}{l}\text { Listening to defaulters excuses to } \\
\text { extend period }\end{array}$ & $13 \%$ & $13 \%$ & $19 \%$ & $25 \%$ \\
\hline Uncommitted debt collectors & $13 \%$ & $19 \%$ & $0 \%$ & $31 \%$ \\
\hline Long repossessing period & $0 \%$ & $19 \%$ & $19 \%$ & $31 \%$ \\
\hline Corrupt staff/officers & $25 \%$ & $0 \%$ & $13 \%$ & $19 \%$ & $13 \%$ \\
\hline
\end{tabular}

\subsubsection{Loan defaulting}

The researcher went ahead to inquire about the overall impact of loan defaults by various variables. $44 \%$ said loan appraisal process has low impact and high impact respectively while $13 \%$ said it has moderate impact. 50\% said credit policies have high impact on loan default, $38 \%$ moderate impact and $13 \%$ said low impact. When asked about loan recovery procedure $50 \%$ said it has high and moderate impact respectively. $42 \%$ said level of interest rates has a low impact, $47 \%$ said it has moderate impact wile $11 \%$ said it has high impact. When asked about management decisions, $47 \%$ said it has moderate impact, $29 \%$ said it has high impact while $24 \%$ said it has low impact and lastly the researcher inquire about the impact of conditions and procedures and $38 \%$ said it has moderate impact, $32 \%$ said it has high impact while 30\% said it has low impact.

Table 4.9 Loan defaulting

\begin{tabular}{|l|l|l|l|}
\hline Variables & Highly & Moderate & Low \\
\hline Loan appraisal process & $44 \%$ & $13 \%$ & $44 \%$ \\
\hline Credit policies & $50 \%$ & $38 \%$ & $13 \%$ \\
\hline Loan recovery procedure & $50 \%$ & $50 \%$ & $0 \%$ \\
\hline Level of interest rates & $11 \%$ & $47 \%$ & $42 \%$ \\
\hline Management decisions & $29 \%$ & $47 \%$ & $24 \%$ \\
\hline Conditions and procedures & $32 \%$ & $38 \%$ & $30 \%$ \\
\hline
\end{tabular}




\subsection{Model Summary}

The R square in the table below indicates that model explains $100 \%$ of the variability in the dependent variable. The Durbin-Watson test is a widely used method of testing for autocorrelation. The Durbin-Watson Statistic is used to test for the presence of serial correlation among the residuals. The value of the DurbinWatson statistic ranges from 0 to 4 . As a general rule of thumb, the residuals are uncorrelated is the DurbinWatson statistic is approximately 2. A value close to 0 indicates strong positive correlation, while a value of 4 indicates strong negative correlation (Durbin and Watson, 1971). Durbin-Watson should be between 1.5 and 2.5 indicating the values are independent (Statistica). For this study, the researcher established Durbin Watson value of 0.5 , this implies that there was a positive correlation among the values, implying a change in any of the values will cause a positive change to the other values and vice versa.

Table 4.10Model summary

\begin{tabular}{|c|c|c|c|c|c|c|c|c|c|c|}
\hline \multirow[t]{2}{*}{ Model } & \multirow[t]{2}{*}{$\mathrm{R}$} & \multirow[t]{2}{*}{ R Square } & \multirow[t]{2}{*}{$\begin{array}{l}\text { Adjusted } \\
\text { R Square }\end{array}$} & \multirow[t]{2}{*}{$\begin{array}{l}\text { Std. Error } \\
\text { of the } \\
\text { Estimate }\end{array}$} & \multicolumn{5}{|c|}{ Change Statistics } & \multirow[t]{2}{*}{$\begin{array}{l}\text { Durbin } \\
\text { Watson }\end{array}$} \\
\hline & & & & & $\begin{array}{l}\text { R Square } \\
\text { Change }\end{array}$ & $\begin{array}{l}\mathrm{F} \\
\text { Change }\end{array}$ & df1 & $\mathrm{df} 2$ & $\begin{array}{l}\text { Sig. F } \\
\text { Change }\end{array}$ & \\
\hline 1 & $1.000(\mathrm{a})$ & 1.000 & 1.000 & & 1.000 & & 2 & 0 & & .500 \\
\hline
\end{tabular}

a Predictors: (Constant), Loan Appraisal Process, Credit Policy

b Dependent Variable: Loan Defaulting

\subsection{Analysis of variance}

In general, the purpose of analysis of variance (ANOVA) is to test for significant differences between means. Elementary Concepts provides a brief introduction to the basics of statistical significance testing. If we are only comparing two means. At the heart of ANOVA is the fact that variances can be divided, that is, partitioned. From the findings the sum of squares under the regression was 12.667 and under residual was 0.0 , the df under regression was 2 , under residual was 0 , the mead square was 6.333 .

Table 4.11 Analysis of variance

\begin{tabular}{|l|l|l|l|l|l|l|}
\hline Model & & $\begin{array}{l}\text { Sum of } \\
\text { Squares }\end{array}$ & df & Mean Square & F & Sig. \\
\hline 1 & Regression & 12.667 & 2 & 6.333 &. &.$($ a) \\
& Residual & .000 & 0 &. & & \\
& Total & 12.667 & 2 &. & & \\
\hline
\end{tabular}

a Predictors: (Constant), Loan Appraisal Process, Credit Policy

b Dependent Variable: Loan Defaulting

\subsection{Correlation Analysis}

This table displays the value of the correlation coefficient and the significance value for each pair of variables used in the Paired Samples T Test procedure.

Since the two variables should represent the same group at different times or two related groups, the correlation should be fairly high and the significance value low (typically less than 0.05 ).

The mean values for the two variables are displayed in the Paired Samples Statistics table. A low significance value for the $t$ test (typically less than 0.05 ) indicates that there is a significant difference between the two variables. If the confidence interval for the mean difference does not contain zero, this also indicates that the difference is significant.

The researcher went further to establish the correlation between the dependent and independent variables, for credit policy and loan appraisal they were positively correlated at $p$. value of 0.222 but the correlation was not significant as the sig. value was 0.603 , for credit policy and loan recovery procedures they were positively correlated at 0.252 but not significant as the sig. value was 0.568 . Loan appraisal process was found to be significantly correlated to the loan recovery procedures at 0.882 and sig. value of 0.046 . Credit policy and loan defaulting the correlation was positive at 0.333 but not significant at 0.602 . The correlation between loan appraisal process and loan defaulting was found to be negatively correlated at -0.816 but not significant while loan recovery procedures and loan defaulting was positively correlated and significant at 0.000. sig. level. 


\section{Table 4.12 Correlation Analysis}

$\mathrm{N}=45$ Sig. 0.05

\begin{tabular}{|l|l|l|l|l|}
\hline & Credit Policy & $\begin{array}{l}\text { Loan } \\
\text { Appraisal } \\
\text { Process }\end{array}$ & $\begin{array}{l}\text { Loan Recovery } \\
\text { Procedures }\end{array}$ & Loan Defaulting \\
\hline Credit Policy & 1.000 & & & \\
& 0.000 & 1.000 & & \\
\hline Loan Appraisal Process & 0.222 & 0.000 & & \\
\hline Loan Recovery Procedures & 0.603 & $0.882(*)$ & 1.000 & \\
& 0.568 & 0.046 & 0.000 & 1.000 \\
\hline Loan Defaulting & 0.333 & -0.816 & 0.000 & 0.000 \\
\hline
\end{tabular}

* Correlation is significant at the 0.05 level (2-tailed).

\subsection{Regression Analysis}

In order to test the research hypotheses, the researcher correlated each of the four independent variables against the dependent variable.

Table 4.13 Credit policy and loan defaulting
Sig. $=0.05$
\begin{tabular}{|l|l|l|l|l|}
\hline & Std. Error Mean & t & df & Sig. \\
\hline Credit Policy & 1.33333 & -1.750 & 2 & 0.222 \\
\hline Loan Appraisal Process & 1.76383 & -2.079 & $\mathbf{2}$ & $\mathbf{0 . 1 7 3}$ \\
\hline Loan Recovery Procedures & 1.45297 & -2.294 & $\mathbf{2}$ & .149 \\
\hline
\end{tabular}

\subsubsection{Credit policy and loan defaulting}

$\mathrm{Ho}_{1}$ : There is no statistically significant difference in loan defaulting due to credit policy The first correlation was between the credit policy as and independent variable against loan defaulting, this was in a bit to evaluate whether the credit policy has any effect on loan defaults. The findings revealed that for credit policy and loan defaulting the $t$ value was -1.750 , thus the hypothesis Hol was rejected.

\subsubsection{Loan appraisal process and loan defaulting}

$\mathrm{Ho}_{2}$ : There is no statistically significant difference in loan defaulting due to initial loan appraisal process

The research regressed the loan default against the initial loan appraisal process, to establish the effect. The tvalue was -2.079 implying there was significance difference between the loan defaulting and loan appraisal process, thus $\mathrm{Ho}_{2}$ was rejected.

\subsubsection{Loan recovery and loan defaulting}

$\mathrm{Ho}_{3}$ : There is no statistically significant difference in loan defaulting due to loan recovery procedures When loan recovery procedures was regressed with loan default to establish the effect of loan recovery procedures on loan default, the t-value was -2.294 thus $\mathrm{Ho}_{3}$ : was rejected

\section{1}

\section{Summary Of Findings, Conclusion And Recommendations}

\section{Summary of Findings}

This study set out to investigate the factors contributing to loan defaulting in micro-finances in Kenya. . The data was collected using questionnaires targeting credit managers of the registered micro-finance institutions in Nairobi County. Out off 48 questionnaires issued 45 were returned back duly filled representing $94 \%$ response rate.

The researcher sought to establish the gender of the respondents from the micro-finance institutions. Majority of the respondents were female forming $56.3 \%$ while the male respondents were $43.8 \%$. The researcher further sought to establish the issue of age bracket; the findings indicated half of the respondents $50 \%$ were below 30 years old, $37.5 \%$ were between $30-40$ years while $12.5 \%$ were between $40-50$ years old

Majority of the respondents had attained the degree level of education forming $62.5 \%$, while $18.8 \%$ had attained diploma and masters levels respectively. When asked to indicate their work experience in their respective organizations, majority of the respondents $31 \%$ had worked for between $2-5$ years, $25 \%$ had worked for between 1-2 years, $18.8 \%$ had worked for between 5-10 years and less than 1 year respectively while $6.3 \%$ had worked for over 10 years.

\subsubsection{Quantitative Analysis}


The analysis started with computation of the descriptive statistics, under the credit policy, the minimum was 12 , maximum 36 , mean 23.4 and standard deviation was 1.67332 , for loan appraisal process, the minimum, maximum ,mean and standard deviations were $11,37,23.2$ and 2.38747 respectively, for loan recovery procedures the minimum, maximum ,mean and standard deviations were 12, 36, 23.2 and 1.788 respectively while for loan defaulting the minimum, maximum , mean and standard deviations were 13, 38, 25.3 and 2.51 respectively.

The researcher went further to establish the correlation between the dependent and independent variables, for credit policy and loan appraisal the correlation was 0.222 and significance was 0.603 , for credit policy and loan recovery procedures the correlation was 0.252 and significance was 0.568 , credit policy and loan defaulting the correlation was 0.333 and significance was 0.602 . The correlation between loan appraisal process and loan recovery procedures was 0.882 and significance was 0.046 , loan appraisal process and loan defaulting the correlation was -0.816 and significance was 0.221 . For loan defaulting and credit policy the correlation was 0.333 while significance was 0.602 .

The mean values for the two variables are displayed in the Paired Samples Statistics table. A low significance value for the $t$ test (typically less than 0.05 ) indicates that there is a significant difference between the two variables. If the confidence interval for the mean difference does not contain zero, this also indicates that the difference is significant.

The $\mathrm{R}$ square in the above table indicates that model explains $100 \%$ of the variability in the dependent variable. The Durbin-Watson test is a widely used method of testing for autocorrelation. The Durbin-Watson Statistic is used to test for the presence of serial correlation among the residuals. The value of the DurbinWatson statistic ranges from 0 to 4 . As a general rule of thumb, the residuals are uncorrelated is the DurbinWatson statistic is approximately 2. A value close to 0 indicates strong positive correlation, while a value of 4 indicates strong negative correlation (Durbin and Watson, 1971). Durbin-Watson should be between 1.5 and 2.5 indicating the values are independent (Statistica). For this study, the researcher established Durbin Watson value of 0.5 , this implies that there was a positive correlation among the values, implying a change in any of the values will cause a positive change to the other values and vice versa.

In general, the purpose of analysis of variance (ANOVA) is to test for significant differences between means. Elementary Concepts provides a brief introduction to the basics of statistical significance testing. If we are only comparing two means. At the heart of ANOVA is the fact that variances can be divided, that is, partitioned. From the findings the sum of squares under the regression was 12.667 and under residual was 0.0 , the df under regression was 2 , under residual was 0 , the mead square was 6.333 .

\subsubsection{Credit policy and loan defaulting}

In order to test the research hypotheses, the researcher correlated each of the four independent variables against the dependent variable. The first correlation was between the credit policy as and independent variable against loan defaulting, this was in a bit to evaluate whether the credit policy has any effect on loan defaults. The findings revealed that for credit policy and loan defaulting the $t$ value was -1.750 , thus the hypothesis Ho1 was rejected.

\subsubsection{Loan appraisal process and loan defaulting}

The research regressed the loan default against the initial loan appraisal process, to establish the effect. The t-value was -2.079 implying there was significance difference between the loan defaulting and loan appraisal process, thus $\mathrm{Ho}_{2}$ was rejected.

\subsubsection{Loan recovery and loan defaulting}

Lastly the researcher sought to establish the effect of loan recovery on the overall loan default rate by the micro-finance institutions. Thus when loan recovery procedures was regressed with loan default to establish the effect of loan recovery procedures on loan default, the t-value was -2.294 thus $\mathrm{Ho}_{3}$ : was rejected.

\subsection{Conclusion}

The general objective of the study was to investigate the factors contributing to loan defaulting in micro-finances in Kenya. The researcher went ahead to test three factors of credit policy, loan appraisal process and loan recovery process against the loan default. In order to test the research hypotheses, the researcher correlated each of the four independent variables against the dependent variable of loan default.

The first correlation was between the credit policy as against loan defaulting, this was in a bit to evaluate whether the credit policy has any effect on loan defaults. The findings revealed that credit policy had a significant impact on loan defaulting. The research regressed the loan default against the initial loan appraisal process, to establish the effect. The findings established a significance difference between the loan defaulting and loan appraisal process, thus there was a significant impact of loan appraisal process on loan default. 
Lastly the researcher sought to establish the effect of loan recovery on the overall loan default rate by the microfinance institutions. Thus when loan recovery procedures was regressed with loan default to establish the effect of loan recovery procedures on loan default, the findings indicated a significant impact of the loan recovery process on loan default rate.

The findings indicated that all the three factors tested had an significant impact on the loan default rate, thus the micro-finance institutions have a cause to worry if they have to reduce the loan default rates by considering the three factors under the study.

\subsection{Recommendations}

Having established that the three factors significantly contribute to loan defaulting in micro-finances in Kenya. It is recommended that the management of micro-finance institutions should take keen interest in the three factors if they have to reduce their loan default portfolio.

The current study considered the registered micro-finance institutions in Kenya, it is recommended that a cross sectional study be undertaken for the micro-finance institutions in East Africa to establish if the factors are the same and forge the way forward.

Since the current study only touched on the micro-finance institutions, it is suggested that a similar study be undertaken targeting the banking sector to establish the factors that contribute to loan default in the banking sector in Kenya.

\section{Acknowledgement}

The MBA programme has been a long, taxing and challenging journey and the successful completion has been as a result of support received from many people. I am indebted not only to people who gave me the inspiration, support and encouragement to purse MBA programme but also to everybody who gave me the guidance and assistance on what has been suggested in this project. Special thanks go to my Supervisor Mr. Fredrick Kalui, Lecturer faculty of business, Egerton University for his continued advice, guidance, availability, encouragement, useful criticism and suggestions throughout the project proposal work. I also thank all the teaching, administrative and support staff of the Egerton University Nairobi Campus for their support throughout the programme period. My dad and mum, wife, relatives and friends thanks a lot for your support. All my classmates and others who in one way or the other gave me support please receive my heartfelt thanks. Above all, special thanks to the Almighty God for the gift of life and good health, lack of which I would not have made it this far.

\section{References}

[1]. Armendariz, B, and Morduch, J. (2005). “MicroFinance: Where Dowe Stand?" In Financial Development and Economic Growth: Explaining the Links, edited by C. Goodhart. Basingstoke: Palgrave Macmillan.

[2]. Buvinic, M. (1997). Women in poverty: A new global underclass. Foreign Policy, 108, 38-53.

[3]. Bystrom, H. (2007). Structured microfinance. Lund University in Lund, Sweden: Swiss printers

[4]. Beatrix, A. \& M. Jonathan, (2005). The Economics of microfinance. London: England Press

[5]. Boldizzoni, F. (2008). "Chapters 4-8". Means and ends: The idea of capital in the West, 1500-1970. New York: Palgrave Macmillan.

[6]. CBK, (2007). Bank supervision Annual Report. Nairobi: Government printers.

[7]. Carter, M. and Eliza, W. (2004) (BASIS CRSD) with WOCCU. Rethinking Rural Finance: A Synthesis of the "Paving the Way Forward for Rural Finance" Conference.

[8]. Chirwa, E.A., (1997). "An econometric analysis of the determinants of agricultural credit payment in Malawi," African Review of Money Finance and Banking, Vol. 1-2: 107-122.

[9]. Chossudovsky, M. (1998). Global poverty in the late 20th century. Journal of International Affairs, 52 ( 1), $293-31$.

[10]. CGAP, (1999). Measuring microcredit delinquency: Occasional paper no. 3 CGAP secretariat1818 h street. Government printers.

[11]. Craig, C. (2006). Making microfinance work.Managing for improved performance. Geneva: International labor office publishers.

[12]. Dinos, C. \& Ashta, A. (2010). Financial Crisis: Lessons from Microfinance in Russia, Ecuador, Bolivia: Swiss Press

[13]. Frankel, J. and Wallen, N. (2000). How to design and evaluate research in Education. London, U.K: McGraw Hill.

[14]. Fofack, H. ( 2005). Nonperforming loans in Sub-Sahara Africa: Causal analysis and macroeconomic implication. World Bank Policy Research Paper 3769 Vol. 21; pp16

[15]. Fidrmuc, J, H. Christa, \& M. Anton, ( 2007); Default rates in the Loan Market for SME. Evidence from Slovakia: Financial Economics Journal, Vol. 67, pp 217-219

[16]. Joana, L. (2000). Microfinance handbook: Sustainable banking with the poor. Washington D.C.: Washington Press.

[17]. Joanna, L. \& V.White. (2006). Transforming Microfinance Institutions. Washington: Washington Press.

[18]. Karimi, I. \& T. Maru (2003). Training manual for Microfinance credit delivery process \& operations. Kenya. USAID/REDSO/ECA press

[19]. Latifee, I. H. (2006). Global Summit 2006.Valladolid, Madrid: Spanish publishers

[20]. Mugenda, F. \& O. Mugenda (1999). The research methods. Nairobi: ACTS Press

[21]. Mugwanga, H., Kashangaki, J., \& D. Hulme (1999). Dropouts among Kenyan microfinancen institutions. Chenai: McGraw-Hill Publishers

[22]. Nunnally, J. C. (1967). Psychometric Theory. New York: McGraw-Hill Publishers.

[23]. Njeru, B. W. (2011). Assessing nonperforming loans in commercial banks in Kenya. Kenya. Kenya Methodist university publication

[24]. Pamoja, MFI. (2010). Pamoja loan book annual report. Nairobi: Saleemi Printers 
[25]. Peeters, H. (2003). Sustainable development and the role of the financial world. Bruxelles: Brussels Printers

[26]. Schreiner, M. (2003). A Cost-Effectiveness Analysis of the Grameen Bank of Bangladesh: St. Louis Publishers

[27]. Saloner, R. (2007). Microfinance in the Developing World: The Effect of Institutional Characteristics on Default Rate. Stanford: Stanford University Press.

[28]. Waweru, N. M. \& V. M. Kalani (2009) .Commercial banking crises in Kenya: causes and remedies. Canada: York University Press

[29]. Srinivasan, R. (2007). Measuring Delinquency and Default in Microfinance Institutions. Indian Institute of Management: working paper No. 254 pp10

[30]. Robinson (2001). Global poverty in the late 20th century. Journal of International Affairs, 52( 1), 293-3 1.

\section{appendix i: questionnaire}

\section{Dear respondent}

You are here provided with a questionnaire for collecting the data to enable the student meet the requirement for the award of a Masters Degree of Egerton University. The information collected will be strictly used for the said purpose and will be held confidential, Kindly tick where appropriate.

Section A: Personal Data

Microfinance institution.

Department /section.

Demographic Data

\begin{tabular}{|c|c|c|c|}
\hline No. & Questions & Answer categories & Tick \\
\hline 1. & Gender & $\begin{array}{ll}\text { 1. } & \text { Male } \\
\text { 2. } & \text { Female }\end{array}$ & \\
\hline 2. & Age bracket & $\begin{array}{ll}\text { 1. } & 18-30 \text { years } \\
\text { 2. } & 30-40 \text { years } \\
\text { 3. } & 40-50 \text { years } \\
\text { 4. } & \text { Above } 50 \text { years }\end{array}$ & \\
\hline 3. & Level of education & $\begin{array}{ll}\text { 1. } & \text { Certificate } \\
\text { 2. } & \text { Diploma } \\
\text { 3. } & \text { Degree } \\
\text { 4. } & \text { Masters } \\
\text { 5. } & \text { Other specify }\end{array}$ & \\
\hline 4. & Work experience with the organization & $\begin{array}{ll}\text { 1. } & \text { Less than } 1 \text { year } \\
\text { 2. } & 1-2 \text { years } \\
\text { 3. } & 2-5 \text { years } \\
\text { 4. } & 5-10 \text { years } \\
\text { 5. } & \text { Over } 10 \text { years }\end{array}$ & \\
\hline
\end{tabular}

\section{Section B: Factors Contributing To Loan Defaulting}

Using the scale 1-5 as shown below, please tick the extent of contribution of the following credit policies on loan defaulting.
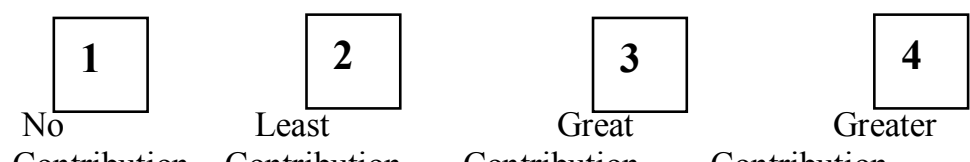

\section{5}

Contribution Contribution

Contribution

Contribution

Greatest

\begin{tabular}{|l|c|c|c|c|c|}
\hline 1 Credit policy & $\mathbf{1}$ & $\mathbf{2}$ & $\mathbf{3}$ & $\mathbf{4}$ & $\mathbf{5}$ \\
\hline (i) Poor loan policies & & & & & \\
\hline (ii) Strict repayment policies & & & & & \\
\hline (iii) Well formulated policies & & & & & \\
\hline (iv) Flexible loan polices & & & & & \\
\hline (v) Poor record keeping policies & & & & & \\
\hline (vi)To what extent does credit policies affect loan defaulting & & & & & \\
\hline
\end{tabular}

Using the scale 1-5 as shown below please tick the extent of contribution of the following loan appraisal processes on loan defaulting.

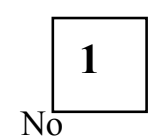

Contribution

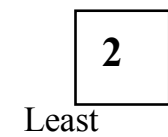

Contribution

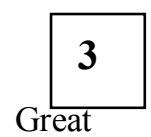

Great

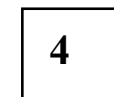

Greater
5
Contribution
Contribution
Contribution 


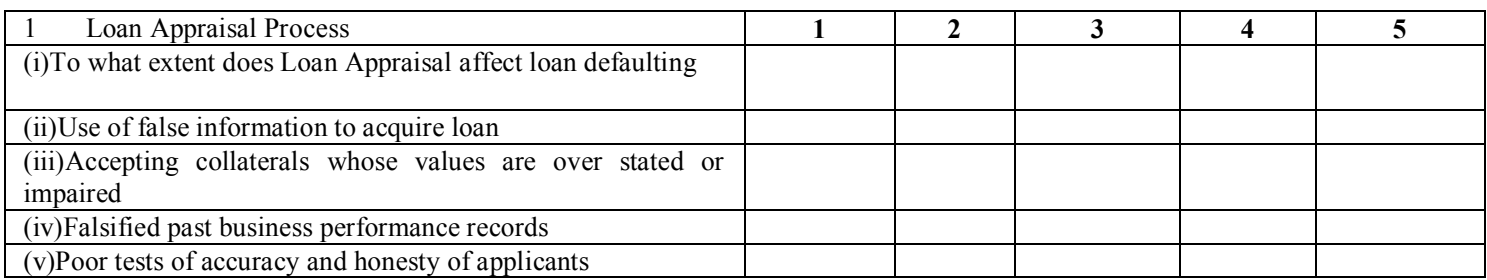

Using the scale 1-5 as shown below please tick the extent of contribution of the following loan recovery procedures on loan defaulting.
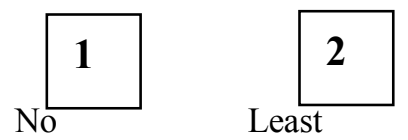

Contribution Contribution

Contribution Contribution

3

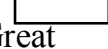

5

Greatest

\begin{tabular}{|c|c|c|c|c|c|}
\hline 3.Loan Recovery Procedures & 1 & 2 & 3 & 4 & 5 \\
\hline (i)Listening to defaulters excuses to extend period & & & & & \\
\hline (ii) Uncommitted debt collectors & & & & & \\
\hline (iii)Long repossessing period & & & & & \\
\hline (iv)Corrupt staff/officers & & & & & \\
\hline
\end{tabular}

Which factors do you think in your own opinion contribute to loan defaulting. Tick them whether highly moderate or low.

\begin{tabular}{|l|l|l|l|}
\hline & Highly & Moderate & Low \\
\hline Loan appraisal process & & & \\
\hline Credit policies & & & \\
\hline Loan recovery procedure & & & \\
\hline Level interest rates & & & \\
\hline Management decisions & & & \\
\hline Conditions and procedures & & & \\
\hline
\end{tabular}

Thank You For Your Time

Appendix Ii: Schedule Of Research Activity

\begin{tabular}{|l|l|l|l|l|l|l|}
\hline $\begin{array}{l}\text { Coming up with a } \\
\text { Researchable Topic }\end{array}$ & March & April & May & June & July & August \\
\hline Writing Chapter One & & & & & & \\
\hline $\begin{array}{l}\text { Writing Chapter Two and } \\
\text { Three }\end{array}$ & & & & & & \\
\hline $\begin{array}{l}\text { Finalizing on the Research } \\
\text { Proposal }\end{array}$ & & & & & & \\
\hline $\begin{array}{l}\text { Research Proposal } \\
\text { Compilation and } \\
\text { Presentation }\end{array}$ & & & & & & \\
\hline Data Collection and analysis & & & & & & \\
\hline $\begin{array}{l}\text { Presentation of final research } \\
\text { project }\end{array}$ & & & & & & \\
\hline
\end{tabular}

